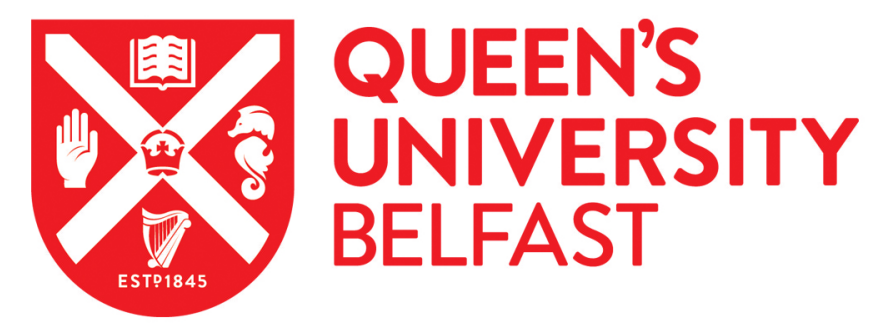

\title{
Effects of EDTA application and arbuscular mycorrhizal colonization on growth and zinc uptake by maize (Zea mays L.) in soil experimentally contaminated with zinc
}

Chen, B. D., Shen, H., Li, X. L., Feng, G., \& Christie, P. (2004). Effects of EDTA application and arbuscular mycorrhizal colonization on growth and zinc uptake by maize (Zea mays L.) in soil experimentally contaminated with zinc. Plant and Soil, 261(1-2), 219-229. https://doi.org/10.1023/B:PLSO.0000035538.09222.ff

Published in:

Plant and Soil

Queen's University Belfast - Research Portal:

Link to publication record in Queen's University Belfast Research Portal

\section{General rights}

Copyright for the publications made accessible via the Queen's University Belfast Research Portal is retained by the author(s) and / or other copyright owners and it is a condition of accessing these publications that users recognise and abide by the legal requirements associated with these rights.

Take down policy

The Research Portal is Queen's institutional repository that provides access to Queen's research output. Every effort has been made to ensure that content in the Research Portal does not infringe any person's rights, or applicable UK laws. If you discover content in the Research Portal that you believe breaches copyright or violates any law, please contact openaccess@qub.ac.uk. 


\title{
Effects of EDTA application and arbuscular mycorrhizal colonization on growth and zinc uptake by maize (Zea mays L.) in soil experimentally contaminated with zinc
}

\author{
Baodong Chen ${ }^{1,2}$, Hong Shen ${ }^{1}$, Xiaolin $\mathrm{Li}^{1,4}$, Gu Feng $^{1}$ \& Peter Christie ${ }^{1,3}$ \\ ${ }^{1}$ Department of Plant Nutrition, China Agricultural University, Beijing, 100094, China. ${ }^{2}$ Present address: De- \\ partment of Soil Environmental Science, Research Center for Eco-Environmental Sciences, CAS, Beijing, 100085, \\ China. ${ }^{3}$ Agricultural and Environmental Science Department, Queen's University Belfast, Newforge Lane, Belfast \\ BT9 5PX, UK. ${ }^{4}$ Corresponding author*
}

Received 26 November 2002. Accepted in revised form 1 May 2003

Key words: arbuscular mycorrhiza, EDTA, phytoremediation, zinc

\begin{abstract}
A pot experiment was conducted to investigate the uptake of $\mathrm{Zn}$ from experimentally contaminated calcareous soil of low nutrient status by maize inoculated with the arbuscular mycorrhizal (AM) fungus Glomus caledonium. EDTA was applied to the soil to mobilize $\mathrm{Zn}$ and thus maximize plant Zn uptake. The highest plant dry matter (DM) yields were obtained with a moderate $\mathrm{Zn}$ addition level of $300 \mathrm{mg} \mathrm{kg}^{-1}$. Plant growth was enhanced by mycorrhizal colonization when no $\mathrm{Zn}$ was added and under the highest $\mathrm{Zn}$ addition level of $600 \mathrm{mg} \mathrm{kg}^{-1}$, while application of EDTA to the soil generally inhibited plant growth. EDTA application also increased plant Zn concentration, and $\mathrm{Zn}$ accumulation in the roots increased with increasing EDTA addition level. The effects of inoculation with G. caledonium on plant $\mathrm{Zn}$ uptake varied with $\mathrm{Zn}$ addition level. When no $\mathrm{Zn}$ was added, $\mathrm{Zn}$ translocation from roots to shoots was enhanced by mycorrhizal colonization. In contrast, when $\mathrm{Zn}$ was added to the soil, mycorrhizal colonization resulted in lower shoot $\mathrm{Zn}$ concentrations in mycorrhizal plants. The $\mathrm{P}$ nutrition of the maize was greatly affected by AM inoculation, with mycorrhizal plants showing higher $\mathrm{P}$ concentrations and $\mathrm{P}$ uptake. The results indicate that application of EDTA mobilized soil $\mathrm{Zn}$, leading to increased $\mathrm{Zn}$ accumulation by the roots and subsequent plant toxicity and growth inhibition. Mycorrhizal colonization alleviated both Zn deficiency and Zn contamination, and also increased host plant growth by influencing mineral nutrition. However, neither EDTA application nor arbuscular mycorrhiza stimulated Zn translocation from roots to shoots or metal phytoextraction under the experimental conditions. The results are discussed in relation to the environmental risk associated with chelate-enhanced phytoextraction and the potential role of arbuscular mycorrhiza in soil remediation.
\end{abstract}

\section{Introduction}

Contamination of agricultural soils with trace metals of geological origin or from human activities has compromised soil environmental quality and poses a potential threat to sustainable agriculture in many parts of the world. There is therefore considerable interest in the development of remediation strategies for contaminated soils, and phytoremediation has emerged as a developing technology. The various remediation

* FAX No.: +86 1062891016 . E-mail: lixl@cau.edu.cn strategies available have been described in several review papers (Cunningham and Ow, 1996; Luo, 1999; McGrath et al., 2002; Salt et al., 1995). One strategy is to grow hyperaccumulator plant species that can accumulate large concentrations of metals in their aerial parts, but which typically have low yields that limit the quantities of metals that they can remove from soils. A second strategy is to grow high-biomass crop plants with lower capacity to accumulate metals, and to optimize metal removal of soil metals by chelateenhanced phytoextraction (Luo, 2000). 
In chelate-enhanced phytoremediation, a chelating agent is applied to the soil to release adsorbed heavy metals from soil solids and thus increase the mobility of the metals in the soil so that certain plants can take up larger quantities of metal. Some of the crop species that could be used for this are typically mycorrhizal, but there is little published information on the effects of chelating agents on mycorrhizas or on the effects of mycorrhizas on plant uptake of heavy metals mobilized using chelating agents.

It is well known that the extraradical mycelium of AM fungi can increase the volume of soil explored by plant roots for the uptake of mineral nutrients (Bolan, 1991; Marschner, 1998). When nutrients of low mobility such as $\mathrm{Zn}, \mathrm{Cu}$ or Fe are in short supply, uptake of these nutrients by plant roots can often be increased by the formation of a mycorrhizal association (Faber et al., 1990; Kothari et al., 1991; Li et al., 1991; Liu et al., 2000). On the other hand, when excessive concentrations of trace metals are present in soils, mycorrhizal plants can contain lower shoot metal concentrations than uninoculated plants growing under similar conditions (Dueck et al., 1986; Leyval et al., 1991; Liu et al., 2000; Tao, 1997). The lower metal concentrations in mycorrhizal plants has often been attributed to larger plant biomass with a resultant 'growth dilution' effect (Nielsen and Jensen, 1983). However, dilution effects cannot explain all the experimental results. In some investigations mycorrhizal plants have absorbed more metals with increasing supply of $\mathrm{Cu}, \mathrm{Ni}, \mathrm{Pb}$ and $\mathrm{Zn}$, or with decreasing soil $\mathrm{pH}$ value, and adverse mycorrhizal effects have sometimes been recorded (Jamal et al., 2002; Killham and Firestone, 1983; Weissenhorn and Leyval, 1995). The effects of AM colonization on metal uptake by host plants are therefore complicated and will depend on the exact conditions in any experimental study.

The significance of arbuscular mycorrhiza in plant uptake of metals from metal-contaminated soils merits systematic studies (Leyval et al., 1997). The wide distribution of AM fungi on metal contaminated sites has shown general adaptation and tolerance of these symbionts to heavy metals (Pawlowska et al., 1996; Shetty et al., 1994a,b), and metal-tolerant fungal strains have been isolated by several research groups (Griffioen, 1994; Hildebrandt et al., 1999; Raman et al., 1993; Weissenhorn et al., 1993, 1994). Recent research has focused on the the role of AM fungi in the stabilization, rather than the remediation, of metal polluted ecosystems (Vangronsveld et al., 1996; Leyval et al., 1997; Khan et al., 2000).
This paper describes an experiment that was designed to investigate the potential for chelate-induced remediation of $\mathrm{Zn}$-contaminated soil using crop plants colonized by an AM fungus. Maize has a high biomass and rapid growth and was adopted as the test plant. We investigated the effects of EDTA application and AM colonization on $\mathrm{Zn}$ uptake and mineral nutrition by maize grown in soil experimentally contaminated with $\mathrm{Zn}$. Our hypothesis was that $\mathrm{Zn}$ uptake, especially shoot accumulation, would be increased by the mobilization of soil $\mathrm{Zn}$ by the chelate EDTA and the metal tolerance of the host plant would be increased by the protective effects of mycorrhizal colonization. As a result, the combination of EDTA application and mycorrhizal colonization might facilitate soil remediation.

\section{Materials and methods}

\section{Mycorrhizal inoculum}

The AM fungus Glomus caledonium (Nicol. \& Gerd.) Trappe \& Gerdemann was originally isolated from a sandy soil in Fengqiu County, Henan Province, and was kindly provided by Professor X.G. Lin of the Institute of Soil Science, Chinese Academy of Sciences. The fungus was propagated in pot culture on maize plants grown in a sandy soil for 10 weeks. Inoculum from pot culture was a mixture of spores, mycelium, sandy soil and maize root fragments containing approximately 1000 spores per $100 \mathrm{~g}$.

\section{Host plants}

Seeds of maize (Zea mays L. cv. ND108) were surface sterilized in a $10 \%(\mathrm{v} / \mathrm{v})$ solution of hydrogen peroxide for $10 \mathrm{~min}$ and immersed in deionized water for $6 \mathrm{~h}$. They were then germinated on moist filter paper for about $24 \mathrm{~h}$ until the radicles appeared. They were selected for uniformity before sowing.

\section{Soil mixture}

A calcareous sandy soil of low nutrient status was employed, but was mixed in a ratio of $3: 1$ with a loam soil to improve its water retention characteristics and to alleviate any potential negative effects of EDTA on plant growth that might perhaps conceal other treatment effects. The sandy soil was collected from the vicinity of Lugouqiao, Fengtai district, Beijing and had the 
following properties (DM basis): $\mathrm{pH}$ (soil: water ratio $1: 2.5) 8.67$, organic matter $0.30 \%$, total $\mathrm{N} 0.018 \%$, $0.5 \mathrm{~mol} \mathrm{~L}^{-1} \mathrm{NaHCO}_{3}$-extractable $\mathrm{P} 3.4 \mathrm{mg} \mathrm{kg}^{-1}$, and $1 \mathrm{~mol} \mathrm{~L}^{-1} \mathrm{NH}_{4} \mathrm{OAc}$-exchangeable $\mathrm{K} 33.6 \mathrm{mg}$ $\mathrm{kg}^{-1}$. The soil extractable trace element concentrations were: $\mathrm{Fe} 4.96, \mathrm{Mn} 4.15, \mathrm{Cu} 0.28$ and $\mathrm{Zn} 0.48 \mathrm{mg}$ $\mathrm{kg}^{-1}$. Soil metals were extracted with a $0.005 \mathrm{~mol}$ $\mathrm{L}^{-1}$ DTPA (diethylene triamine pentaacetic acid) $0.01 \mathrm{~mol} \mathrm{~L}^{-1} \mathrm{CaCl}_{2}-0.1 \mathrm{~mol} \mathrm{~L}^{-1}$ TEA (triethanolamine) solution at $\mathrm{pH}$ 7.30. The calcareous loam soil was collected from Yizishan village, Zhenzi town, Tangshan City, Hebei Province and had the following properties (DM basis): pH 7.60, organic matter $0.83 \%$, total $\mathrm{N} 0.027 \%, 0.5 \mathrm{~mol} \mathrm{~L}^{-1} \mathrm{NaHCO}_{3}$-extractable $\mathrm{P}$ $9.7 \mathrm{mg} \mathrm{kg}^{-1}$, and $1 \mathrm{~mol} \mathrm{~L}^{-1} \mathrm{NH}_{4} \mathrm{OAc}$-exchangeable $\mathrm{K} 60.0 \mathrm{mg} \mathrm{kg}^{-1}$. Extractable trace element concentrations were: $\mathrm{Fe} 2.60, \mathrm{Mn} 8.35, \mathrm{Cu} 0.45$ and $\mathrm{Zn} 1.36 \mathrm{mg}$ $\mathrm{kg}^{-1}$. The soils were passed through a $1-\mathrm{mm}$ sieve, sterilized by autoclaving at $120^{\circ} \mathrm{C}$ for $2 \mathrm{~h}$ and then air-dried. Prior to the experiment the sandy soil and loamy soil were mixed in a ratio of $3: 1$ and the soil mixture was used as the cultivation medium. The soil mixture had a $\mathrm{pH}$ value (soil: water ratio, 1:2.5) of 8.18, DTPA-extractable $\mathrm{Zn} 0.44 \mathrm{mg} \mathrm{kg}^{-1}$, and $0.5 \mathrm{~mol}$ $\mathrm{L}^{-1} \mathrm{NaHCO}_{3}$-extractable P $3.96 \mathrm{mg} \mathrm{kg}^{-1}$. In this paper, the term 'soil' in the context of the present study refers to the mixture of the two soils.

\section{Experimental procedure}

Three $\mathrm{Zn}$ addition levels (0, 300 and $600 \mathrm{mg}$ $\mathrm{kg}^{-1}$ )were applied as analytical grade $\mathrm{ZnSO}_{4}$ solution mixed thoroughly with the soil. The solutions were prepared in deionized water and mixed with the soil manually. There were three EDTA application levels of $0,2.5$ and $10 \mathrm{mmol} \mathrm{kg}^{-1}$ (E0, E2.5 and E10), and maize plants were either inoculated with $(+\mathrm{M})$ the AM fungus $G$. caledonium or uninoculated controls (M) under all $\mathrm{Zn}$ addition and EDTA application levels. Thus, there were 18 treatments in total with 3 replicates, giving a total of 54 pots in a randomized block design. All treatments received a basal application of mineral nutrients added in solution to each compartment at rates of $300 \mathrm{mg} \mathrm{N}\left(\mathrm{NH}_{4} \mathrm{NO}_{3}\right), 20 \mathrm{mg} \mathrm{P}$ $\left(\mathrm{KH}_{2} \mathrm{PO}_{4}\right)$, and $150 \mathrm{mg} \mathrm{K}\left(\mathrm{K}_{2} \mathrm{SO}_{4}\right) \mathrm{kg}^{-1}$ soil.

Round plastic pots were used, each containing 2.0 $\mathrm{kg}$ of soil. Firstly, $1.5 \mathrm{~kg}$ soil was placed in the pot, then mycorrhizal inoculum, and finally the remainder of the soil. Inoculum was placed about $2 \mathrm{~cm}$ below the soil surface. Mycorrhizal treatments received 100 $\mathrm{g}$ of inoculum, while non-inoculated plants received an equivalent amount of sterilized inoculum together with an aqueous filtrate $(0.25 \mu \mathrm{m}$ pore size $)$ of unsterilized soil to provide a similar microflora except for the absence of the mycorrhizal fungus. Five germinated seeds (carefully selected for uniformity) were sown in each pot and 7 days after seedling emergence these were thinned to 3 seedlings. During the experimental period deionized water was used to maintain a moisture content of $15 \%$ (DM basis) by regular weighing.

The experiment was conducted in the glasshouse of the Department of Plant Nutrition, China Agricultural University, Beijing, and the plants grew for 7 weeks from 25 April 2001 to 6 June 2001 under natural light conditions with no supplementary illumination. During the period of plant growth the day temperature ranged from $20^{\circ} \mathrm{C}$ to $30^{\circ} \mathrm{C}$ and the night temperature from $15^{\circ} \mathrm{C}$ to $20^{\circ} \mathrm{C}$. At the start of the experiment, there were $\mathrm{Zn}$ addition and $\mathrm{AM}$ inoculation treatments only (6 treatments and 9 replicates each). EDTA was applied in solution 1 week before harvest ( 7 weeks after seedling emergence) at 3 application levels as described above for each $\mathrm{Zn}$ addition level and AM inoculation treatment. After a further growth period of 1 week the maize plants were harvested.

Leaves, stems (including leaf bases) and roots were harvested separately after growth for 8 weeks. Samples were carefully washed with tap water and then deionized water. Sub-samples of fresh roots were collected for determination of AM colonization rate. The dry weights of leaves, stems and roots were determined after oven drying at $70^{\circ} \mathrm{C}$ for $48 \mathrm{~h}$. Ovendried sub-samples were milled to pass through a 0.5 $\mathrm{mm}$ sieve and dry ashed at $560^{\circ} \mathrm{C}$ for multi-element analysis by inductively coupled plasma-atomic emission spectroscopy (ICP-AES) (Sun et al., 2002; Sahrawat et al., 2000). Soil P was determined colorimetrically by the vanadomolybdate method, and $\mathrm{Zn}$ and other trace metals by atomic absorption spectrophotometry (AAS) using standard methods. Samples for assessing root colonization were prepared using the acid fuchsin staining-grid intersect method (Giovannetti and Mosse, 1980; Kormanik et al., 1979). Data were tested by three-way analysis of variance and means were compared by LSD at the 5\% level. 
Table 1. Proportion of maize root length colonized by the mycorrhizal fungus

\begin{tabular}{|c|c|c|c|}
\hline \multirow{2}{*}{$\begin{array}{l}\text { Zn addition level } \\
\left(\mathrm{mg} \mathrm{kg}^{-1}\right)\end{array}$} & \multirow{2}{*}{$\begin{array}{l}\text { Inolculation } \\
\text { treatment }\end{array}$} & \multicolumn{2}{|c|}{ Root infection rate $(\%)$} \\
\hline & & $\mathrm{E} 0^{1}$ & E 2.5 $\quad$ E 10 \\
\hline \multirow[t]{2}{*}{0} & $-\mathrm{M}^{2}$ & $0.0 c^{3}$ & $0.0 \mathrm{~d} \quad 0.0 \mathrm{c}$ \\
\hline & $+\mathrm{M}$ & $76.9 \mathrm{a}$ & $72.9 \mathrm{a} \quad 76.1 \mathrm{a}$ \\
\hline \multirow[t]{2}{*}{300} & $-\mathrm{M}$ & $0.0 \mathrm{c}$ & $0.0 \mathrm{~d} \quad 0.0 \mathrm{c}$ \\
\hline & $+\mathrm{M}$ & $49.6 b$ & $51.0 \mathrm{~b} \quad 55.5 \mathrm{~b}$ \\
\hline \multirow[t]{2}{*}{600} & $-\mathrm{M}$ & $0.0 \mathrm{c}$ & $0.0 \mathrm{~d}$ \\
\hline & $+\mathrm{M}$ & $46.4 \mathrm{~b}$ & $43.0 \mathrm{c} \quad 50.3 \mathrm{~b}$ \\
\hline \multicolumn{4}{|l|}{ Significance $^{4}$ of: } \\
\hline $\mathrm{Zn}$ addition level & & & $* * *$ \\
\hline Inoculation & & & $* * *$ \\
\hline EDTA application rate & & & ns \\
\hline $\mathrm{Zn} \times$ inoculation & & & $* * *$ \\
\hline $\mathrm{Zn} \times \mathrm{EDTA}$ & & & ns \\
\hline Inoculation $\times$ EDTA & ns & & \\
\hline
\end{tabular}

${ }^{1}$ E0, E2.5, E10: EDTA application rate of 0, 2.5 and $10 \mathrm{mmol}$ $\mathrm{kg}^{-1}$.

${ }^{2}-\mathrm{M},+\mathrm{M}$ : uninoculated control, inoculation with the mycorrhizal fungus $G$. caledonium.

${ }^{3}$ In each column, means followed by the same letter are not significantly different by LSD at the $5 \%$ level.

4 By analysis of variance; ${ }^{* *}, p<0.001 ;$ ns, not significant.

\section{Results}

\section{Mycorrhizal colonization}

No root infection was detected in the non-inoculated plants, while inoculated plants had relatively high infection rates (Table 1). When no $\mathrm{Zn}$ was added the rate of root colonization exceeded $70 \%$, while mycorrhizal colonization was markedly inhibited by $\mathrm{Zn}$ addition as the proportion of root length colonized decreased to around $50 \%$. There was no significant difference in root colonization rate between the two $\mathrm{Zn}$ addition levels, and EDTA application had no detectable influence on root colonization rate.

\section{Plant growth}

The highest dry biomass of maize plants occurred under the $\mathrm{Zn}$ addition level of $300 \mathrm{mg} \mathrm{kg}^{-1}$, followed by the zero-Zn controls (except for foliar $\mathrm{P}$ contents), and the lowest dry biomass occurred under the highest $\mathrm{Zn}$ addition level of $600 \mathrm{mg} \mathrm{kg}^{-1}$ (Table 2). Actually, mild symptoms of Zn phytotoxicity were detected under the highest $\mathrm{Zn}$ addition level with the plants showing stunted growth and the young leaves especially appearing etiolated, but no symptoms were

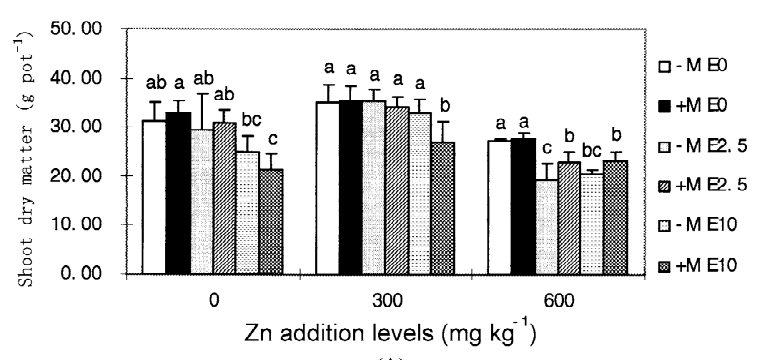

(A)

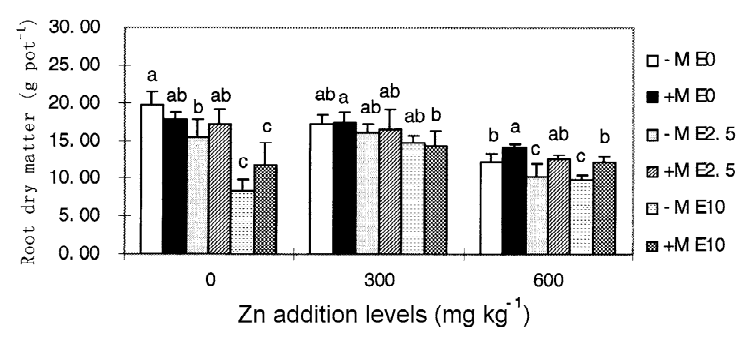

(B)

Figure 1. Shoot (A) and root (B) dry matter yield of maize plants under different treatments. $-\mathrm{M}$ and $+\mathrm{M}$ represent non-inoculation treatment and inoculation with mycorrhizal fungus G. caledonium, and E0, E2.5 and E10 represent EDTA application rate of 0, 2.5 and $10 \mathrm{mmol} \mathrm{kg}^{-1}$. Different letters above the columns indicate significant difference between means by LSD at the 5\% level. By analysis of variance, both $\mathrm{Zn}$ addition level and EDTA application rate were highly significant $(p<0.001)$ and inoculation had a significant effect $(p<0.05)$ on root yield but not shoot yield. The interaction between $\mathrm{Zn}$ and EDTA rates was significant for both shoot $(p<0.05)$ and root $(p<0.001)$ yields.

Table 2. Dry matter yield of maize under different $\mathrm{Zn}$ addition levels 1

\begin{tabular}{|c|c|c|c|}
\hline \multirow{2}{*}{$\begin{array}{l}\text { Zn addition levels } \\
\left(\mathrm{mg} \mathrm{kg}^{-1}\right)\end{array}$} & \multicolumn{3}{|c|}{ Dry weight $\left(\mathrm{g} \mathrm{pot}^{-1}\right)$} \\
\hline & Leaves & Stems & Roots \\
\hline 0 & $17.67 \mathrm{~b}$ & $10.89 b$ & $15.05 \mathrm{a}$ \\
\hline 300 & $20.98 \mathrm{a}$ & $12.37 \mathrm{a}$ & $16.07 \mathrm{a}$ \\
\hline 600 & $15.57 \mathrm{c}$ & $7.92 \mathrm{c}$ & $11.85 b$ \\
\hline \multicolumn{4}{|l|}{ Significance $^{2}$ of: } \\
\hline $\mathrm{Zn}$ addition level & $* * *$ & $* * *$ & $* * *$ \\
\hline Inoculation & ns & ns & * \\
\hline EDTA application rate & $* * *$ & $* * *$ & $* * *$ \\
\hline $\mathrm{Zn} \times$ inoculation & ns & ns & ns \\
\hline $\mathrm{Zn} \times \mathrm{EDTA}$ & $*$ & ns & $* * *$ \\
\hline Inoculation $\times$ EDTA & ns & ns & ns \\
\hline
\end{tabular}

${ }^{1}$ Means of 18 replicates of all EDTA application and inoculation treatments under the same $\mathrm{Zn}$ addition level.

${ }^{2}$ By analysis of variance; ${ }^{* * *}, p<0.001 ;{ }^{*}, p<0.05$; ns, not significant. 
observed under the $\mathrm{Zn}$ addition level of $300 \mathrm{mg} \mathrm{kg}^{-1}$. Under all $\mathrm{Zn}$ addition levels, plant dry weight tended to decrease with increasing EDTA application rate, and at the EDTA application rate of $10 \mathrm{mmol} \mathrm{kg}^{-1}$, maize plants showed significantly lower shoot and root dry weights compared with plants receiving no EDTA (Figure 1A, B). The EDTA application rate of $10 \mathrm{mmol} \mathrm{kg}^{-1}$ also led to obvious plant withering under the zero-zinc treatment, but somewhat surprisingly this was not the case when $\mathrm{Zn}$ was added.

Plant growth was generally enhanced by mycorrhizal colonization, especially under the highest $\mathrm{Zn}$ addition level of $600 \mathrm{mg} \mathrm{kg}^{-1}$ under which mycorrhizal treatments produced significantly larger root dry weights than did uninoculated controls (Figure 1A, B). However, with a few specific exceptions, there were no significant differences in shoot dry weight (sum of leaf dry weight and stem dry weight) between mycorrhizal and non-inoculated treatments. Mycorrhizal colonization also showed no marked effects on root growth when no $\mathrm{Zn}$ was added and under the $\mathrm{Zn}$ addition level of $300 \mathrm{mg} \mathrm{kg}^{-1}$.

\section{Zn uptake and partitioning}

Figure 2 shows that $\mathrm{Zn}$ concentrations of maize plants increased markedly with increasing $\mathrm{Zn}$ addition levels. Compared with the controls, $\mathrm{Zn}$ concentrations of maize leaves, stems and roots under the $\mathrm{Zn}$ addition level of $600 \mathrm{mg} \mathrm{kg}^{-1}$ increased 30-, 40- and 50-fold, respectively. Under all $\mathrm{Zn}$ addition levels, $\mathrm{Zn}$ concentrations of roots and leaves also increased with increasing EDTA application rate, but stem Zn concentrations were not greatly affected by EDTA applications.

Mycorrhizal colonization showed diverse effects on $\mathrm{Zn}$ concentrations of maize plants depending on the experimental treatments. When no $\mathrm{Zn}$ was added, foliar $\mathrm{Zn}$ concentrations generally increased, stem $\mathrm{Zn}$ concentrations were slightly affected, and root $\mathrm{Zn}$ concentrations tended to decrease with mycorrhizal colonization. An exception was the highest EDTA application rate under which foliar $\mathrm{Zn}$ concentrations showed no significant difference between mycorrhizal and non-inoculated treatments, but stem $\mathrm{Zn}$ concentrations of mycorrhizal plants were significantly higher than those of uninoculated plants. Under the $\mathrm{Zn}$ addition level of $300 \mathrm{mg} \mathrm{kg}^{-1}$ and with no EDTA applied (or at the EDTA application rate of $2.5 \mathrm{mmol}$ $\mathrm{kg}^{-1}$ ), mycorrhizal colonization tended to decrease foliar $\mathrm{Zn}$ concentrations and increase stem and root $\mathrm{Zn}$ concentrations, but no significant differences were

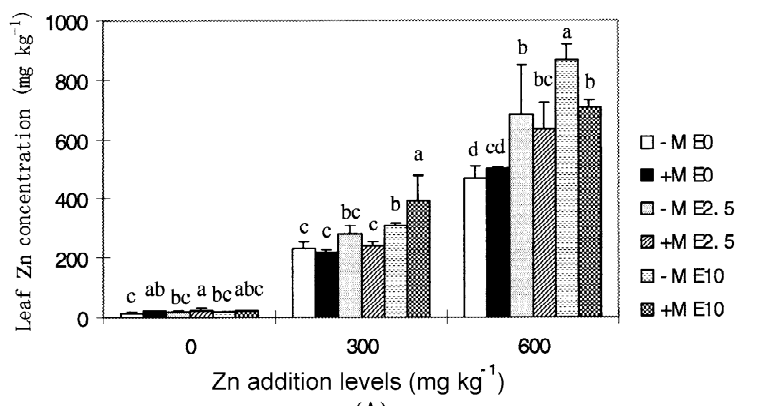

(A)

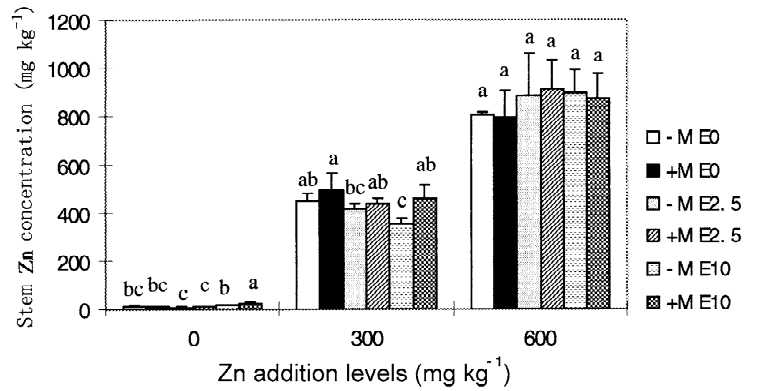

(B)

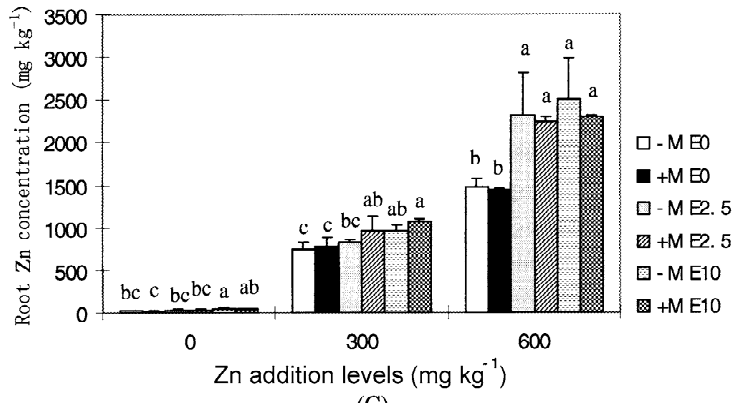

(C)

Figure 2. Zn concentration of maize leaves (A), stems (B) and roots (C) under different treatments. $-\mathrm{M}$ and $+\mathrm{M}$ represent non-inoculation and inoculation with the mycorrhizal fungus $G$. caledonium, and E0, E2.5 and E10 represent EDTA application rate of $0,2.5$ and $10 \mathrm{mmol} \mathrm{kg}^{-1}$. Different letters above the columns indicate significant difference between means by LSD at the 5\% level. $\mathrm{By}$ analysis of variance, $\mathrm{Zn}$ addition level was highly significant $(p<0.001)$ in all three plant components, and EDTA application rate and the interaction between $\mathrm{Zn}$ addition rate and EDTA application rate were also highly significant $(p<0.001)$ in leaves and roots.

found between mycorrhizal and uninoculated treatments. However, at the EDTA application rate of $10 \mathrm{mmol} \mathrm{kg}{ }^{-1}$, foliar, stem and root $\mathrm{Zn}$ concentrations were all significantly increased by mycorrhizal colonization. Under the highest $\mathrm{Zn}$ addition level of $600 \mathrm{mg} \mathrm{kg}^{-1}$, mycorrhizal colonization decreased plant $\mathrm{Zn}$ concentrations overall, and especially foliar $\mathrm{Zn}$ concentrations. Under the $10 \mathrm{mmol} \mathrm{kg}{ }^{-1}$ EDTA application rate, foliar $\mathrm{Zn}$ concentrations of mycor- 


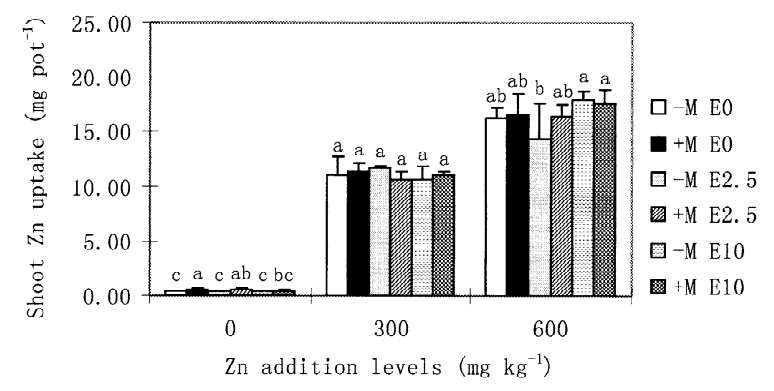

(A)

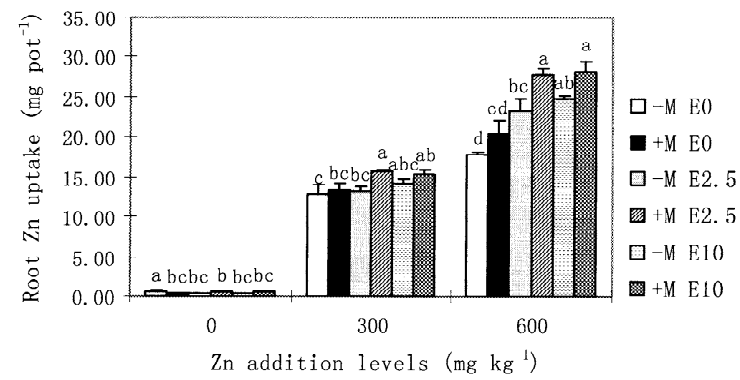

(B)

Figure 3. Zn uptake by maize shoots (A) and roots (B) under different treatments. $-\mathrm{M}$ and $+\mathrm{M}$ represent non-inoculation treatment and inoculation with the mycorrhizal fungus $G$. caledonium, and E0, E2.5 and E10 represent EDTA application rate of 0, 2.5 and 10 $\mathrm{mmol} \mathrm{kg}-1$. Different letters above the columns indicate significant difference between means by LSD at the 5\% level. By analysis of variance, shoot $\mathrm{Zn}$ uptake was highly significantly affected by $\mathrm{Zn}$ addition level $(p<0.001)$ and root $\mathrm{Zn}$ uptake by $\mathrm{Zn}$ addition level, inoculation and EDTA application rate (all $p<0.001$ ). In root $\mathrm{Zn}$ uptake there were significant interactions between $\mathrm{Zn}$ addition level and EDTA application rate $(p<0.001)$ and between $\mathrm{Zn}$ addition level and inoculation $(p<0.01)$.

rhizal plants were significantly lower than those of corresponding uninoculated plants.

Zn uptake by maize plants also markedly increased with increasing $\mathrm{Zn}$ addition level, while EDTA application generally had no discernible effect on shoot $\mathrm{Zn}$ uptake, and the same held for root $\mathrm{Zn}$ accumulation in the zero- $\mathrm{Zn}$ treatment and the $\mathrm{Zn}$ addition level of $300 \mathrm{mg} \mathrm{kg}^{-1}$ (Figure 3A, B). However, EDTA application significantly increased $\mathrm{Zn}$ uptake by roots under the $\mathrm{Zn}$ addition level of $600 \mathrm{mg} \mathrm{kg}^{-1}$.

Mycorrhizal effects on $\mathrm{Zn}$ uptake by maize plants varied with $\mathrm{Zn}$ addition level, and were influenced by EDTA application. When no Zn was added, shoot $\mathrm{Zn}$ uptake was significantly increased by mycorrhizal colonization. On the other hand, root Zn uptake of mycorrhizal plants was significantly lower than controls when no EDTA was applied, but this difference disappeared under EDTA applications. With Zn addition, shoot $\mathrm{Zn}$ uptake was not affected by the inoculation

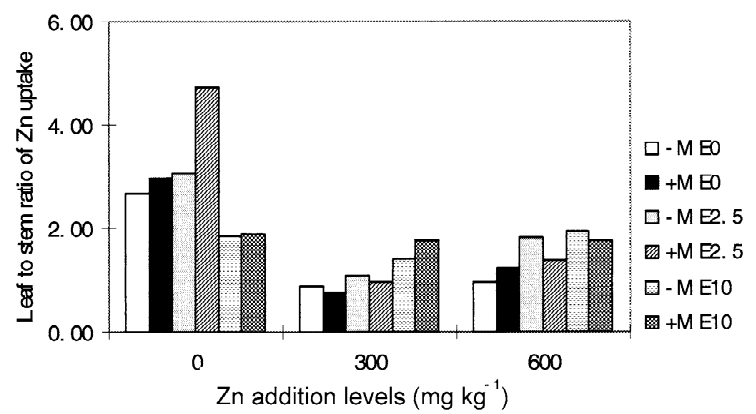

(A)

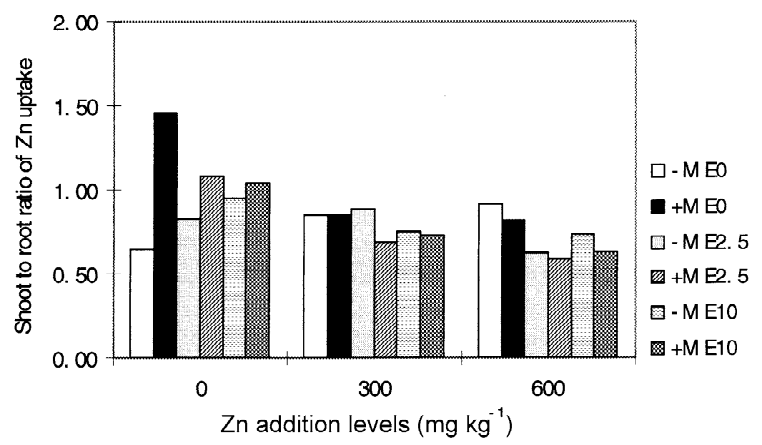

(B)

Figure 4. Zn partitioning in maize plants under different treatments. $-\mathrm{M}$ and $+\mathrm{M}$ represent uninoculated treatments and inoculation with the mycorrhizal fungus $G$. caledonium, and E0, E2.5 and E10 represent EDTA application rate of $0,2.5$ and $10 \mathrm{mmol} \mathrm{kg}^{-1}$.

treatments, but root $\mathrm{Zn}$ accumulation was increased by mycorrhizal colonization. At the $2.5 \mathrm{mmol} \mathrm{kg}-1$ EDTA application rate, $\mathrm{Zn}$ uptake by mycorrhizal roots was significantly higher than that in uninoculated roots.

Leaf-to-stem and shoot-to-root ratios of $\mathrm{Zn}$ uptake reflected $\mathrm{Zn}$ partitioning at the plant organ level. Figure 4 shows that mycorrhizal plants generally took up higher leaf-to-stem and shoot-to-root ratios of $\mathrm{Zn}$ than did corresponding controls when no $\mathrm{Zn}$ was added. Mycorrhizal colonization had clearly facilitated $\mathrm{Zn}$ transport from the roots to the aerial parts and also translocation to the leaves. With increasing EDTA application rates shoot-to-root ratio of $\mathrm{Zn}$ uptake in uninoculated plants tended to increase, with the opposite trend in mycorrhizal treatments. Under $\mathrm{Zn}$ addition, the mycorrhizal effects on $\mathrm{Zn}$ partitioning in the plants were reversed, with mycorrhizal plants generally showing lower leaf-to-stem and shoot-toroot ratios of $\mathrm{Zn}$ uptake than controls. This may be indicative of mycorrhizal inhibition of $\mathrm{Zn}$ transport from roots to shoots and translocation to leaves. With increasing EDTA application rate, leaf-to-stem ratio of 


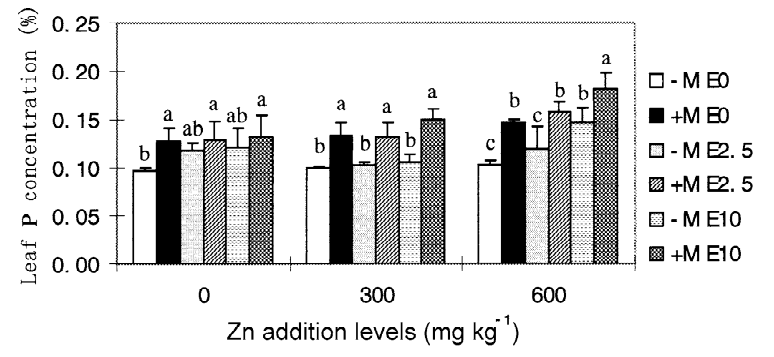

(A)

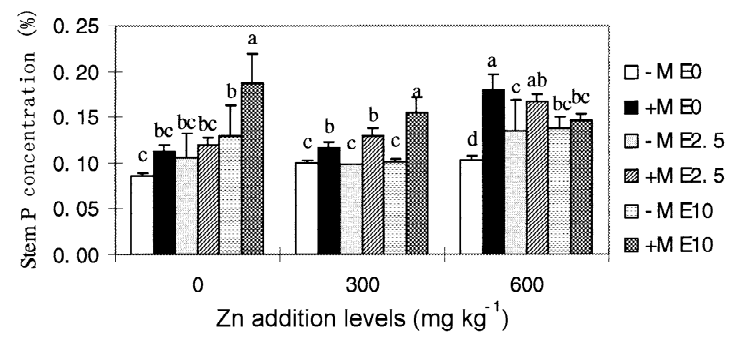

(B)

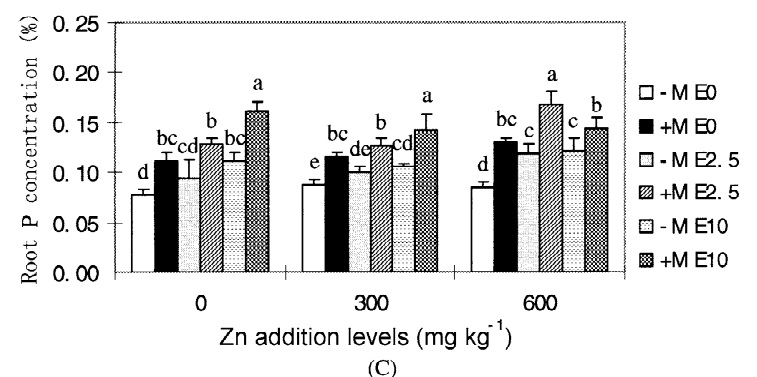

Figure 5. $\mathrm{P}$ concentration of maize leaves (A), stems (B) and roots (C) under different treatments. $-\mathrm{M}$ and $+\mathrm{M}$ represent non-inoculation and inoculation with the mycorrhizal fungus $G$. caledonium, and E0, E2.5 and E10 represent EDTA application rate of $0,2.5$ and $10 \mathrm{mmol} \mathrm{kg}^{-1}$. Different letters above the columns indicate significant difference between means by LSD at the $5 \%$ level. For results of three-way ANOVA, see Table 3.

$\mathrm{Zn}$ uptake tended to increase, and the opposite trend occurred in shoot-to-root ratio, indicating that EDTA had enhanced $\mathrm{Zn}$ accumulation in plant roots and $\mathrm{Zn}$ partitioning to leaves in the aerial parts of the plants.

\section{Plant phosphorus nutrition}

$\mathrm{P}$ concentrations in the leaves, stems and roots of the maize plants were generally increased by mycorrhizal colonization (Figure 5), and also tended to increase with increasing EDTA application rate. One exception was stem P concentration, which decreased with increasing EDTA application rate under the $\mathrm{Zn}$ addition level of $600 \mathrm{mg} \mathrm{kg}^{-1}$, and under the $\mathrm{Zn}$ addition level of $300 \mathrm{mg} \mathrm{kg}^{-1}$, leaf and stem P concentrations in non-inoculated plants were unaffected by EDTA

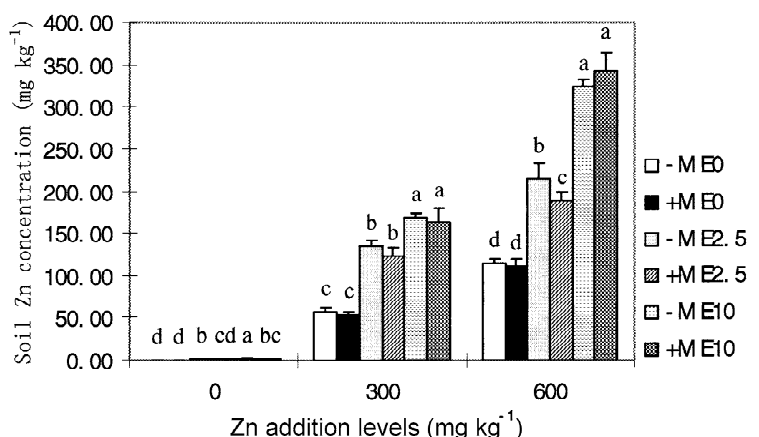

$(\Lambda)$

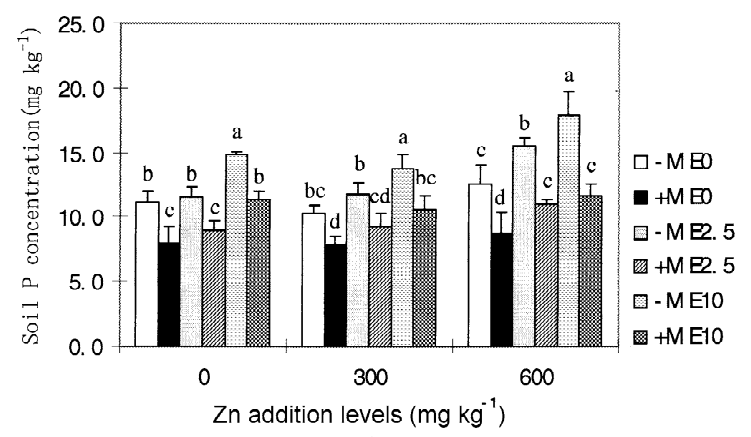

(B)

Figure 6. Soil DTPA-extractable $\mathrm{Zn} \quad$ (A) and $0.5 \quad \mathrm{M}$ $\mathrm{NaHCO}_{3}$-extractable $\mathrm{P}(\mathrm{B})$ of different treatments after harvest. $-\mathrm{M}$ and $+\mathrm{M}$ represent non-inoculation treatment and inoculation with the mycorrhizal fungus G. caledonium, and E0, E2.5 and E10 represent EDTA application rate of $0,2.5$ and $10 \mathrm{mmol}$ $\mathrm{kg}^{-1}$. Different letters above the columns indicate significant difference between means by LSD at the 5\% level. By analysis of variance, $\mathrm{Zn}$ addition level and EDTA application rate were highly significant for extractable $\mathrm{P}$ and $\mathrm{Zn}$ and inoculation for extractable $\mathrm{P}($ all $p<0.001)$. The interaction between $\mathrm{Zn}$ level and EDTA rate was significant for extractable $\mathrm{Zn}(p<0.001)$ and that between inoculation and $\mathrm{Zn}$ level for extractable $\mathrm{P}(p<0.01)$.

application. Maize plants contained the highest $\mathrm{P}$ concentrations under the $\mathrm{Zn}$ addition level of $600 \mathrm{mg} \mathrm{kg}^{-1}$ (Table 3).

Mycorrhizal plants generally took up more $\mathrm{P}$ than corresponding uninoculated plants. Zinc addition and EDTA application had similar effects on plant $P$ uptake to those on plant growth: plant $\mathrm{P}$ uptake decreased with increasing EDTA application rate (data not shown), and the highest $\mathrm{P}$ uptake by leaves, stems and roots occurred under the $\mathrm{Zn}$ addition level of $300 \mathrm{mg} \mathrm{kg}^{-1}$, followed by those receiving no $\mathrm{Zn}$ addition (except for foliar $P$ concentration), and the lowest $P$ uptake under the highest $\mathrm{Zn}$ addition level of $600 \mathrm{mg}$ $\mathrm{kg}^{-1}$ (Table 3). 
Table 3. $\mathrm{P}$ concentration and $\mathrm{P}$ uptake of maize leaves, stems and roots under different $\mathrm{Zn}$ addition levels ${ }^{1}$

\begin{tabular}{|c|c|c|c|c|c|c|}
\hline \multirow{2}{*}{$\begin{array}{l}\text { Zn addition levels } \\
\left(\mathrm{mg} \mathrm{kg}^{-1}\right)\end{array}$} & \multicolumn{3}{|c|}{$\mathrm{P}$ concentration $(\%)$} & \multicolumn{3}{|c|}{ P uptake $\left(\mathrm{mg} \mathrm{pot}^{-1}\right)$} \\
\hline & Leaves & Stems & Roots & Leaves & Stems & Roots \\
\hline 0 & $0.12 b$ & $0.12 b$ & $0.12 b$ & $21.08 b$ & $12.74 b$ & $16.66 b$ \\
\hline 300 & $0.12 b$ & $0.12 b$ & $0.11 \mathrm{~b}$ & $25.09 \mathrm{a}$ & $14.04 \mathrm{a}$ & $18.05 \mathrm{a}$ \\
\hline 600 & $0.14 \mathrm{a}$ & $0.15 \mathrm{a}$ & $0.13 \mathrm{a}$ & $22.17 b$ & $11.41 \mathrm{c}$ & $15.25 \mathrm{c}$ \\
\hline \multicolumn{7}{|l|}{ Significance $^{2}$ of: } \\
\hline $\mathrm{Zn}$ addition level & $* * *$ & $* * *$ & $* * *$ & $* * *$ & $* * *$ & $* * *$ \\
\hline Inoculation & $* * *$ & $* * *$ & $* * *$ & $* * *$ & $* * *$ & $* * *$ \\
\hline EDTA application rate & $* * *$ & $* * *$ & $* * *$ & ns & ns & $* *$ \\
\hline $\mathrm{Zn} \times$ inoculation & $\mathrm{ns}$ & ns & $\mathrm{ns}$ & $*$ & $\mathrm{~ns}$ & $*$ \\
\hline $\mathrm{Zn} \times \mathrm{EDTA}$ & ns & $* * *$ & $* * *$ & $* * *$ & $* *$ & $*$ \\
\hline Inoculation $\times$ EDTA & ns & ns & $\mathrm{ns}$ & ns & $*$ & ns \\
\hline
\end{tabular}

${ }^{1}$ Means of 18 replicates of all EDTA application and inoculation treatments under the same $\mathrm{Zn}$ addition level.

${ }^{2}$ By analysis of variance; ${ }^{* * *}, p<0.001 ;{ }^{* *}, p<0.01 ;{ }^{*}, \mathrm{p}<0.05$; ns, not significant.

\section{Soil extractable Zn and P concentrations after harvest}

After harvest, concentrations of extractable soil $\mathrm{Zn}$ tended to be higher with increasing $\mathrm{Zn}$ addition level and EDTA application rate (Figure 6A). Soil Zn concentration in mycorhizal treatments was generally lower than corresponding uninoculated treatments, but significant differences were only occasionally found (Figure 6A).

Concentrations of residual soil available $\mathrm{P}$ were greatly affected by mycorrhizal treatment, with soil $\mathrm{P}$ concentration in all mycorrhizal treatments significantly lower than in corresponding uninoculated controls (Figure 6B). With increasing EDTA application rate, soil $\mathrm{P}$ concentrations increased markedly (Figure 6B), and the highest residual $\mathrm{P}$ concentrations occurred under the $600 \mathrm{mg} \mathrm{kg}^{-1} \mathrm{Zn}$ addition level (data not shown).

\section{Discussion}

Although in some cases application of metals may entirely eliminate AM colonization (Gildon and Tinker, 1983), high levels of mycorrhizal colonization have been reported in both heavily contaminated mine spoils and agricultural soils contaminated with metals of different origins (Diaz and Honrubia, 1993; Weissenhorn et al., 1995a,b). It can therefore be concluded that adaptation to metal contamination could occur in these soil microorganisms under field conditions. The results of the present study also indicate some tolerance to $\mathrm{Zn}$ contamination in our fungal strain. Although mycorrhizal colonization was markedly inhibited by $\mathrm{Zn}$ addition to the soil, root colonization rates higher than $50 \%$ were still observed under $\mathrm{Zn}$ contamination. It would be interesting to carry out further investigations on the behaviour of this fungal strain in naturally contaminated soil, together with the responses of fungal isolates from naturally contaminated sites to experimental $\mathrm{Zn}$ additions.

In the present study, growth of maize was not inhibited by $\mathrm{Zn}$ addition of $300 \mathrm{mg} \mathrm{kg}^{-1}$. In fact, this treatment produced significantly larger plant dry matter compared with pots to which no $\mathrm{Zn}$ additions were made. Plant dry weight showed a clear decrease only under the highest $\mathrm{Zn}$ addition level of $600 \mathrm{mg} \mathrm{kg}^{-1}$. One explanation is that the soil supply of $\mathrm{Zn}$ could not meet the demand for maximum growth when no $\mathrm{Zn}$ was added (Marschner, 1993). The Zn supply under the $\mathrm{Zn}$ addition level of $300 \mathrm{mg} \mathrm{kg}^{-1}$ may have been excessive for the maize plants but below a level that would have led to zinc phytotoxicity (Hinsely et al. 1977; MacNicol and Beckett, 1985).

In addition to direct toxicity, a possible reason for the general and marked inhibition on plant growth by EDTA may have been an imbalance in mineral nutrition. Enhanced $\mathrm{Zn}$ accumulation in roots due to $\mathrm{Zn}$ mobilization by EDTA could inhibit root growth under $\mathrm{Zn}$ contamination and other metals could also be mobilized by EDTA, as indicated by increased Fe, Mn and $\mathrm{Cu}$ concentrations with increasing EDTA application levels (data not shown). Physiological activities of roots, including nutrient and water transport and 
metabolism could suffer severe inhibition from metal toxicity. When no Zn was added, EDTA increased Zn uptake by the roots only, with no increase in $\mathrm{Zn}$ transport to the shoots. In contrast, when $\mathrm{Zn}$ was added, although EDTA application did not increase shoot Zn uptake compared with corresponding treatments with no EDTA application, Zn was partitioned to the leaves, resulting in $\mathrm{Zn}$ phytotoxicity, despite the occurrence of only mild symptoms in the present study. However, while foliar Fe concentrations were unaffected, foliar $\mathrm{Mn}$ and $\mathrm{Cu}$ were increased by EDTA application (data not shown). The resulting imbalances among mineral nutrients may have contributed to the observed decrease in plant growth. It is true that under the $\mathrm{Zn}$ addition level of $600 \mathrm{mg} \mathrm{kg}^{-1} \mathrm{Fe}$ and $\mathrm{P}$ concentrations in the stems decreased with increasing EDTA application level, but this effect would have exacerbated any deficiency of $\mathrm{Fe}$ and $\mathrm{P}$ in plants under high $\mathrm{Zn}$ additions.

Our data indicate that EDTA made little contribution to $\mathrm{Zn}$ phytoextraction, especially by increasing shoot $\mathrm{Zn}$ uptake. Moreover, the negative effects of EDTA on plant growth, in addition to potential environmental risks, such as metal leaching to the ground water (Madrida et al., 2003; Romkens et al., 2002), would need to be considered in practical phytoremediation. Certainly, we cannot make the general conclusion from the present study that metal chelates would not be useful in phytoextraction of soil metals, as some chelating agents could have higher mobilizing capacity for different metals. Other investigations have indicated that EDTA is a powerful mobilizing agent for increasing $\mathrm{Pb}$ concentrations in the soil solution and in plant shoots, and $\mathrm{Pb}$ uptake by plant shoots showed high correlations with soil solution $\mathrm{Pb}$ concentration (Blaylock et al., 1997; Huang et al., 1997). Furthermore, the partitioning pattern of metals in plants has been found to differ among plant species (Guo and Marschner, 1995). It would be more important to choose a suitable plant species with the potential of efficient uptake and translocation of mobilized metals for the purpose of phytoextraction.

Under our experimental conditions, when no $\mathrm{Zn}$ was added or under the $300 \mathrm{mg} \mathrm{kg}^{-1} \mathrm{Zn}$ addition level, mycorrhizal colonization generally showed no marked growth benefit to the host plants, with even the mycorrhizal plants showing lower shoot dry weight than corresponding controls when high doses of EDTA were applied to the soil. The apparent decrease in plant biomass by mycorrhizal colonization may have been due to immobilization of excessive metal in mycorrhizal structures (mycorrhizal roots contained much higher metal concentrations than uninoculated roots), with resulting high metal concentrations exerting direct phytotoxic effects on the host plant roots. In addition, the soil mixture may have provided adequate available $\mathrm{P}$ for plant growth in the absence of mycorrhizal colonization, which may have lowered the mycorrhizal dependency of the maize plants.

However, the protective effects of arbuscular mycorrhiza on plant growth under the $\mathrm{Zn}$ addition level of $600 \mathrm{mg} \mathrm{kg}^{-1}$ were still notable. Under such severe $\mathrm{Zn}$ contamination, the mycorrhizal effect may have resulted from direct binding of metal by fungal mycelium (Joner et al., 2000), resulting in reduced $\mathrm{Zn}$ partitioning to the shoots, together with lower shoot (especially leaf) $\mathrm{Zn}$ concentrations due to growth dilution effects (as total $\mathrm{Zn}$ uptake showed no decrease). The strong metal binding capacity of arbuscular mycorrhiza (which tended to be more pronounced with the increasing $\mathrm{Zn}$ addition levels) may have played an important role in alleviation of $\mathrm{Zn}$ phytotoxicity. Furthermore, improved $\mathrm{P}$ nutrition of the host plants by mycorrhiza may have had some effect under conditions of $\mathrm{Zn}$ contamination. Phosphate in the roots may have immobilized metals, while in the shoots increased $\mathrm{P}$ concentration may have helped to maintain the balance of mineral nutrients. In contaminated field sites excessive heavy metals are often associated with a shortage of available mineral nutrients, especially $\mathrm{P}$ (Shetty et al., 1994a,b). Thus, arbuscular mycorrhiza might improve the survival of plants on contaminated soils through improvement of plant $\mathrm{P}$ nutrition.

In conditions where mycorrhizal colonization had no significant effect on plant growth (under the zero$\mathrm{Zn}$ treatment and the $\mathrm{Zn}$ addition level of $300 \mathrm{mg}$ $\mathrm{kg}^{-1}$ ), the direct involvement of AM fungi in plant metal uptake can be evaluated because there is no growth dilution effect on metal concentrations in mycorrhizal plants to mask the direct effects. In the present study, when no $\mathrm{Zn}$ was added shoot $\mathrm{Zn}$ uptake was increased and root $\mathrm{Zn}$ accumulation decreased with mycorrhizal colonization. $\mathrm{Zn}$ transport from roots to shoots clearly increased. On the other hand, when $\mathrm{Zn}$ was added mycorrhizal colonization resulted in higher Zn uptake by the roots but had no marked effect on shoot $\mathrm{Zn}$ uptake. Therefore, enhanced binding of $\mathrm{Zn}$ by mycorrhiza may have played an important role in metal tolerance of the host plants under $\mathrm{Zn}$ contamination. Mycorrhizal colonization showed different effects on $\mathrm{Zn}$ uptake by the host plants under different $\mathrm{Zn}$ addition levels. There may have been a 
critical plant tissue or soil available $\mathrm{Zn}$ concentration below which $\mathrm{Zn}$ uptake by plants and partitioning to shoots could be increased by mycorrhizal colonization, and above which the protective effects of the mycorrhiza would appear. Chen et al. (2003) suggested a threshold for $\mathrm{Zn}$ of $50 \mathrm{mg} \mathrm{kg}^{-1}$ soil based on their experimental data. Clearly, this value is likely to differ according to soil type, plant species and cultivar, and would need to be determined on a site-specific basis.

Soil extractable $\mathrm{P}$ concentrations tended to increase with increasing EDTA application rate. The chelation of soil metals by EDTA may have facilitated the release of $\mathrm{P}$ from inorganic compounds. Soil extractable $\mathrm{Zn}$ concentration together with $\mathrm{Zn}$ accumulation in roots also increased due to EDTA application, but most of the mobilized $\mathrm{Zn}$ was not transported to the aerial parts. Furthermore, mycorrhizal colonization decreased available soil $\mathrm{Zn}$ concentrations and large amounts of $\mathrm{Zn}$ were retained in the mycorrhiza. The data lead to the general conclusion that the combined effects of EDTA and AM colonization did not promote metal removal from the soil. Shoot metal uptake was negligible compared with the application rates of $\mathrm{Zn}$ studied in the experiment. However the results provided further evidence for the alleviation of heavy metal phytotoxicity by arbuscular mycorrhiza. More detailed studies are required to elucidate fully the potential role of AM fungi in phytoremediation of metal contaminated soils.

\section{Acknowledgements}

We thank the National Natural Science Foundation of China (Projects 40071050 and 3023250 ) and the Major State Basic Research Development Program of the People's Republic of China (Project G1999011808) for generous financial support and two anonymous reviewers for their valuable comments on the manuscript.

\section{References}

Blaylock M J, Salt S E, Dushenkov S, Zakharova O, Gussman C, Kapulnik Y, Ensley B D and Raskin I 1997 Enhanced accumulation of $\mathrm{Pb}$ in Indian mustard by soil-applied chelating agents. Environ. Sci. Technol. 31, 860-865.

Bolan N S, 1991 A critical review on the role of mycorrhizal fungi in the uptake of phosphorus by plants. Plant Soil 134, 189-207.

Chen B D, Li X L, Tao H Q, Christie P and Wong M H 2003 The role of arbuscular mycorrhiza in zinc uptake by red clover grow- ing in a calcareous soil spiked with various quantities of zinc. Chemosphere 50, 839-846.

Cunningham S D and Ow D W 1996 Promises and prospects of phytoremediation. Plant Physiol. 110, 715-719.

Diaz G and Honrubia M 1993 Infectivity of mine soils from southeast Spain. II. Mycorrhizal population levels in spoilt sites. Mycorrhiza 4, 85-88.

Dueck T A, Visser P, Ernst W H O and Schat H 1986 Vesiculararbuscular mycorrhizae decrease zinc toxicity to grasses growing in zinc polluted soil. Soil Biol. Biochem. 18, 331-333.

Faber B A, Zazoski R J, Burau R G and Uriu K 1990 Zinc uptake by corn as affected by vesicular-arbuscular mycorrhizae. Plant Soil 129, 121-130.

Gildon A and Tinker P B, 1983. Interactions of vesicular-arbuscular mycorrhizal infection and heavy metals in plants. I. The effects of heavy metals on the development of vesiculat-arbuscular mycorrhizas. New Phytol. 95, 247-261.

Giovannetti M and Mosse B 1980 An evaluation of techniques for measuring vesicular- arbuscular mycorrhizal infection in roots. New Phytol. 84, 489-500

Griffioen W A J 1994 Characterization of a heavy metal-tolerant endomycorrhizal fungus from the surroundings of a zinc refinery. Mycorrhiza 4, 197-200.

Guo Y T and Marschner H 1995 Uptake, distribution and binding of cadium and nickel in different plant species. J. Plant Nutr. 8, 2691-2706.

Hildebrandt U, Kaldorf M and Bothe H 1999 The zinc violet and its colonization by arbuscular mycorrhizal fungi. J. Plant Physiol. 154, 709-717.

Hinesly T D Jones R L Ziegler E L and Tyler J J, 1977 Effects of annual and accumulative applications of sewage sludge on assimilation of zinc and cadmium by corn (Zea mays L.). Environ. Sci. Technol. 11, 182-188.

Huang J W W, Chen J J, Berti W R and Cunningham S D 1997 Phytoremediation of lead contaminated soils: Role of synthetic chelates in lead phytoextraction. Environ. Sci. Technol. 31, 800805.

Jamal A, Ayub N, Usman M and Khan A G 2002 Arbuscular mycorrhizal fungi enhance zinc and nickel uptake from contaminated soil by bean and lentil. Int. J. Phytorem. 4, 205-221.

Joner E J, Briones R and Leyval C 2000 Metal-binding capacity of arbuscular mycorrhizal mycelium. Plant Soil 226, 227-234.

Khan A G, Kuek C, Chaudhry T M, Khoo C S and Hayes W J 2000 Role of plants, mycorhizae and phytochelators in heavy metal contaminated land remediation. Chemosphere 41, 197-207.

Killham K and Firestone M K 1983 Vesicular-arbuscular mycorrhizal mediation of grass response to acidic and heavy metal depositions. Plant Soil 72, 39-48.

Kormanik P P, Bryan W C and Schultz R C 1979 Procedures and equipment for staining large numbers of plant root samples for mycorrhizal assay. Can. J. Microbiol. 26, 537-538.

Kothari S K, Marschner H and Romheld V 1991 Contribution of the VA mycorrhizal hyphae in acquisition of phosphorus and zinc by maize grown in a calcareous soil. Plant Soil 131, 177-185.

Leyval C, Berthelin J, Schontz D, Weissenhorn I and Morel J L 1991 Influence of endomycorrhizas on maize uptake of $\mathrm{Pb}, \mathrm{Cu}$ and $\mathrm{Cd}$ applied as mineral salts or sewage sludge. In Heavy Metals in the Environment. Ed. J G Farmer. pp. 204-207. CEP Consultants, Edinburgh.

Leyval C, Turnau K and Haselwandter K 1997 Effect of heavy metal pollution on mycorrhizal colonization and function: Physiological, ecological and applied aspects. Mycorrhiza 7, 139-153. 
Li X L, Marschner H and George E 1991 Acquisition of phosphorus and copper by VA mycorrhizal hyphae and root to shoot transport in white clover. Plant Soil 136, 49-57.

Liu A, Hamel C, Hamilton R I, Ma B L and Smith D L 2000 Acquisition of $\mathrm{Cu}, \mathrm{Zn}, \mathrm{Mn}$ and $\mathrm{Fe}$ by mycorrhizal maize (Zea mays L.) grown in soil at different $\mathrm{P}$ and micronutrient levels. Mycorrhiza 9, 331-336.

Luo Y M 1999 Phytoremediation of metal contaminated soils. Soils 31, 261-265.

Luo Y M 2000 Chelate-induced phytoremediation: Technology and environmental risks. Soils 32, 57-61.

MacNicol R D and Beckett H T 1985 Critical tissue concentrations of potentially toxic elements. Plant Soil 85, 107-129.

McGrath S P, Zhao F J and Lombi E 2002 Phytoremediation of metals, metalloids, and radionuclides. Adv. Agron. 75, 1-56.

Madrida F, Liphadzib M S and Kirkham M B, 2003. Heavy metal displacement in chelate-irrigated soil during phytoremediation. J. Hydrol. 272, 107-119.

Marschner H 1993 Zinc uptake from soils. In Zinc in Soils and Plants. Ed. A D Robinson. pp. 59-77. Kluwer, Dordrecht. The Netherlands.

Marschner H 1998 Role of root growth, arbuscular mycorrhiza and root exudates for the efficiency in nutrient acquisition. Field Crops Res. 56, 203-207.

Nielsen J D and Jensen A 1983 Influence of vesicular-arbuscular mycorrhizal fungi on growth and uptake of various nutrients as well as uptake ratio of fertilizer P for lucerne (Medicago sativa). Plant Soil 70, 165-172.

Pawlowska T E, Blaszkowski J and Ruhling A 1996 The mycorrhizal status of plants colonizing a calamine spoil mound in southern Poland. Mycorrhiza 6, 499-505.

Raman N, Nagarajan N, Gopinathan S and Sambandan K 1993 Mycorrhizal status of plant species colonizing a magnesite mine spoil in India. Biol. Fertil. Soils 16, 76-78.

Romkens P, Bouwman L, Japenga J and Draaisma C 2002 Potentials and drawbacks of chelate-enhanced phytoremediation of soils. Environ. Pollut. 116, 109-121.
Salt D E, Blaylock M, Kumar N P B A, Dushenkov V, Ensley B D, Chet I and Raskin I 1995 Phytoremediation: A novel strategy for the removal of toxic metals from the environment using plants. Biotechnology 13, 468-474.

Shetty K G, Banks M K, Hetrick B A D and Schwab A P 1994a Biological characterization of a southeast Kansas mining site. Water Air Soil Pollut. 78, 169-177.

Shetty K G, Hetrick B A D, Figge D A H and Schwab A P 1994b Effects of mycorrhizae and other soil microbes on revegetation of heavy metal contaminated mine spoil. Environ. Pollut. 86, 181188.

Tao H Q 1997 Effect of arbuscular mycorrhiza on resistance of red clover to heavy metal $\mathrm{Zn}$ and $\mathrm{Cd}$ pollution. MS thesis, China Agricultural University, Beijing.

Vangronsveld J, Colpaert J V and Van Tichelen K K 1996 Reclamation of a bare industrial area contaminated by non-ferrous metals: Physico-chemical and biological evaluation of the durability of soil treatment and revegetation. Environ. Pollut. 94, 131-140.

Weissenhorn I and Leyval C 1995 Root colonization of maize by a Cd-sensitive and a Cd-tolerant Glomus mosseae and cadmium uptake in sand culture. Plant Soil 175, 233-238.

Weissenhorn I, Leyval C and Berthelin J 1993 Cd-tolerant arbuscular mycorrhizal (AM) fungi from heavy metal polluted soil. Plant Soil 157, 247-256.

Weissenhorn I, Glashoff A, Leyval C and Berthelin J 1994 Differential tolerance to $\mathrm{Cd}$ and $\mathrm{Zn}$ of arbuscular mycorrhizal (AM) fungal spores isolated from heavy metal polluted and unpolluted soils. Plant Soil 167, 189-196.

Weissenhorn I, Leyval C and Berthelin J 1995a Biovailability of heavy metals and abundance of arbuscular mycorrhiza in a soil polluted by atmospheric deposition from a smelter. Biol. Fertil. Soils 19, 22-28.

Weissenhorn I, Mench M and Leyval C 1995b Biovailability of heavy metals and arbuscular mycorrhizas in a sewage sludge amended sandy soil. Soil Biol. Biochem. 27, 287-296. 